\title{
Necessity of "Historic Cultural Heritage and Conservation" Course in Interior Architecture Education
}

\author{
Özlem Atalan ${ }^{1 \mathrm{a}}$ and Zeynep Sevinç ${ }^{1}$ \\ ${ }^{1}$ Izmir University, Faculty of Architecture, Gürsel Aksel Bulvarı No: 14, Izmir 35340, Turkey
}

\begin{abstract}
For five decades, academics and architects have been debating the subject of historical conservation techniques. Nowadays, much of building activities take place in historic areas. Most of the architects and interior architects are engaged to renovation or restoration of historical buildings. Architectural education is considered to be a complex process. Teaching the historical cultural heritage and conservation of historic structures constitutes an important part of architectural education. So, it is essential for students of architecture and interior architecture to be aware of the philosophy of conservation of historic cultural heritage. The course of "Historic Cultural Heritage and Conservation" which is about cultural heritage and principles, takes place in the undergraduate curriculum in the architecture and interior architecture departments of Izmir University. By this course knowledge of conservation, and restoration techniques were introduced. While students were taking this course also they were working on a studio project about a case study of an historical building. This paper considers the students' approach to conservation and reuse of old warehouse building, in the scope of studio project. The aim of this paper is to show how the students were referred to conservation techniques on their studio projects while taking "Historic Cultural Heritage and Conservation" course.
\end{abstract}

Keywords: teaching cultural heritage; teaching conservation; architectural education; interior architectural education; historical cultural heritage

\section{Introduction}

Historic cities and buildings are one of the important elements of our cultural heritage. These areas are defined as milieu that possesses the historic evidence of cultural values. That should be conceived as carrying or possessing the traces of all kind of historic events and processes. Historic environments are also the places that enable the social and cultural

\footnotetext{
${ }^{a}$ Corresponding author: oatalan@hotmail.com
} 
connections. The details of social and economic life of past civilizations are carried through generation by the historic environments [1].

There are lots of examples of studies on historic cultural heritage and conservations in different parts of the world. For instance; in Turkey, there are variety of historical environments that have their own unique characteristics, especially in Mardin, Urfa, Karadeniz, Şirince, Tire, Kula, Cumalıkızık and Safranbolu. These examples are important in the area of historical environment. Furthermore, Sözen [13], Küçükerman [10] and Gür's (2000) studies on Turkish houses, Eldem's [5] works on "Bosphorus Residences" and Günay's [8] works on "Safranbolu Houses" are examples from historical environment studies from Turkey.

Historical environment and vernacular architecture is an area of architectural theory that focuses on human needs local \& traditional building techniques and materials. In other words, historical environment and vernacular architecture are combinations of climate conditions, simple construction techniques, traditions and socioeconomic conditions of the region, which has evolved empirically [9].

Conservation philosophy has some mandatories such as; providing necessary measures, conserving the cultural heritage elements and analyzing the contemporary usage. It is mention in the 13. Article of Venice Charter [14] that; "Additions cannot be allowed except in so far as they do not detract from the interesting parts of the building, its traditional setting, the balance of its composition and its relation with its surroundings". While reusing or projecting an old building for usage of in modern life, required additions might be added. For instance; an old building which is renovated as a museum, needs to have some additional parts such as security area, modern toilets and service areas. In this case, additions that are suitable for the new environment should be used. The physical appearance of the building should not be damaged while renovating the building. It is acceptable to apply flexible solution on the exterior, and applying new interior organizations in the interior [1].

Due to in time, and changing lifestyles, depending upon the requests many historical structures have lost their original functions and they adapted to serve a different function from the original purpose, such as monasteries, baths, caravanserais, and warehouses. Today, the old buildings using for housing and hotel may have valid functions, however they do not have adequate comfort conditions to competewith today's buildings. Unless, they are updated or renovated they are abounded and ruined. Therefore,in architectural and interior architectural education teaching preserving and restoration techniques of cultural heritage and vernacular architecture are important for students.

\subsection{Objectives of Teaching Historic Cultural Heritage and Conservation}

One of the main objectives of the course "Historic Cultural Heritage and Conservation" was teaching the methods and techniques used for the reuse, renovation and conservation of historical environments and buildings which are cultural heritages from past centuries. Also, in this course basic knowledge on the local and rural materials and techniques of restoration need to be introduced. Course includes the topics of; history of conservation, variety of cultural properties, types of the site areas, causing factors of the historical environments degeneration, preparation process of surveying, restoration methods and techniques and lastly legal regulations on conservation.

By this course students have gained the consciousness of taking attention to Historic Cultural Heritage and restoration methods and techniques. By teaching of this course; students were expected to use their knowledge that they have gained on their 5th semester design project. So, the knowledge they have gathered was expected to be used on the 
potential reuse of the case building. In addition, they were expected to show their knowledge on critical judgment, communication, thinking and decision making processes.

Teaching historic cultural heritage is not a new trend in architectural education, even from 1920's by Gustavo Giovannoni who introduced conservation into university didactics. He pioneered the need of studying and conserving historical sites, and environments in architectural education [11].

\section{Method}

With total of 27 students' projects who were taking the course of "Historic Cultural Heritage and Conservation" and "Studio of Interior Design III" as a final project during the 5 th semester were analyzed in this study. The project was given to the 3rd year students as a final project of fall semester. The project was a historical warehouse building in the city of Izmir, Alsancak district. They were asked to renovate the masonry building for Chamber of Interior Architect in Izmir.

Firstly, students had field measurements and gathered historical information about the building, and then six groups of (4-5 people) students had surveyed the building. Surveying took two weeks and whilst they took photographs, measurements and site analyses. Whole project took 14 weeks (1 semester period), remained time from the survey, students developed and designed their projects. At the end of the semester they were required to submit 1/50 renovation plan(s), at least 2 sections and 4 elevations that showing their design concepts. This study aimed to see students' knowledge about historic cultural heritage and restoration methods and techniques on their design projects.

At the end of the semester, the projects were evaluated in to two criteria. The first criterion was interventions on plan scheme and second one was interventions on façade (Table 1).

Table 1. Consideration criteria of the projects

\begin{tabular}{|c|c|}
\hline Interventions On Plan Scheme & Interventions On Façade \\
\hline $\begin{array}{l}\text { Conservation of the original plan } \\
\text { schemes }\end{array}$ & $\begin{array}{l}\text { Conservation of original façade system } \\
\text { (windows, doors, shutters, arcs, etc.) }\end{array}$ \\
\hline $\begin{array}{l}\text { Conservation of the intrinsic structural } \\
\text { condition }\end{array}$ & Conservation of the original façade height \\
\hline Usage original building material & Usage of original building material \\
\hline $\begin{array}{l}\text { Usage of contemporary structural } \\
\text { addition }\end{array}$ & Usage of contemporary structural addition \\
\hline Usage of contemporary material & Usage of contemporary material \\
\hline
\end{tabular}

\section{Case study}

\subsection{Information about Case Building}

The case building was located in city of Izmir in Turkey, Izmir city has 4,000 years of recorded urban history and hosted to multiple nations. The city income mostly depends on trade of importation and exportation. Therefore, during $19^{\text {th }}$ century, multiple storages and warehouses were constructed in the areas closer to the harbor.

The case building was constructed on 1825 as a tobacco storage for Samuel Levi family. Building was located on the intersection point of 1347 and 1349 streets. Building was set 
on an area of $800 \mathrm{~m}^{2}$ with height of $7.80 \mathrm{~m}$. There were two entrances centered on latitudinal facades and the building is adjacent to the next building on one longitudinal side and on the other longitudinal side there is an alley between the next buildings (Figure 1). Today, the building is serving as a parking lot in the neighborhood.
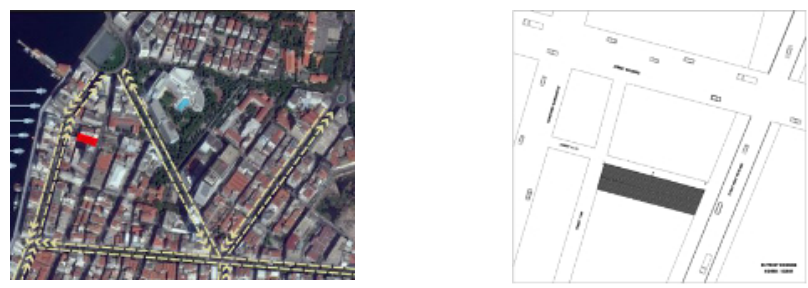

Fig. 1.Location of the case building

The building is inclusive of 2 nd degree preservation construction. Students were expected to renovate the building in the scope of legal legislation procedures of 2 nd degree preservation construction. According to law No. 2863, 2nd group buildings, which were constructed by the traditional fabricating techniques and gives the characteristics of the region such as; old factories, warehouses, 19th century inns and residential units; façade of the building should be conserved and interventions can only be applied to the interior [1]. All the information including historical conservation legislations and differences between degrees were all introduced to the students in the scope of "Historic Cultural Heritage and Conservation" course.

a
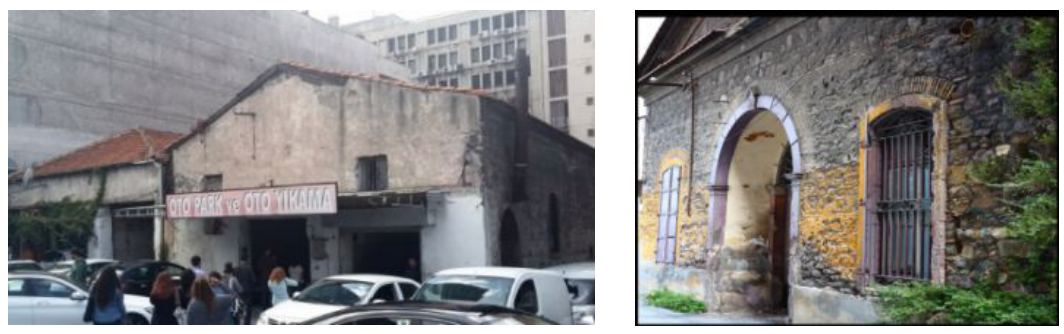

b

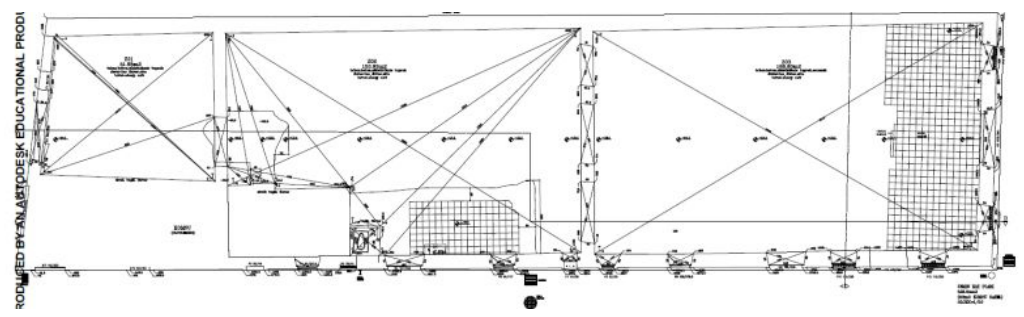

$\mathrm{c}$

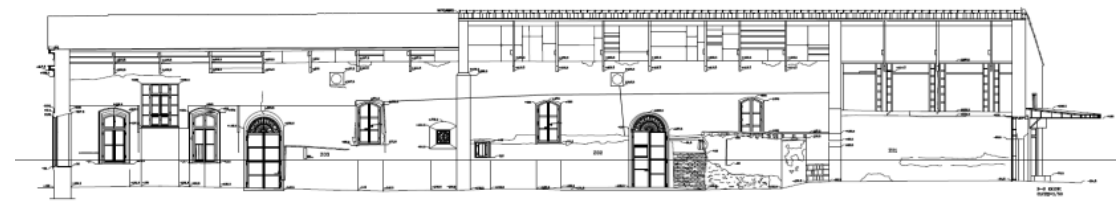


d
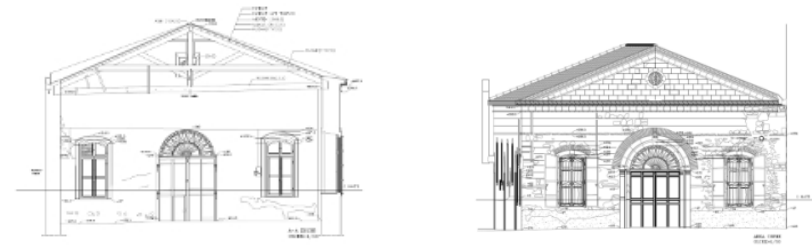

$\mathrm{e}$

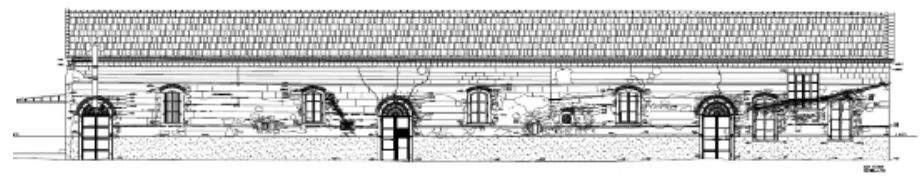

Fig. 2. (a) façade of the building; (b) plan; (c) longitudinal section; (d) latitudinal sections; (e) longitudinal elevation drawings (Rölöve) (Drawn by: Arkayın,A.T.)

\subsection{Student Project Evaluation}

In this part of the paper, 27student projects will be analyzed and according to preservation and conservation principles, which was thought on Historic Cultural Heritage and Conservation course.

a

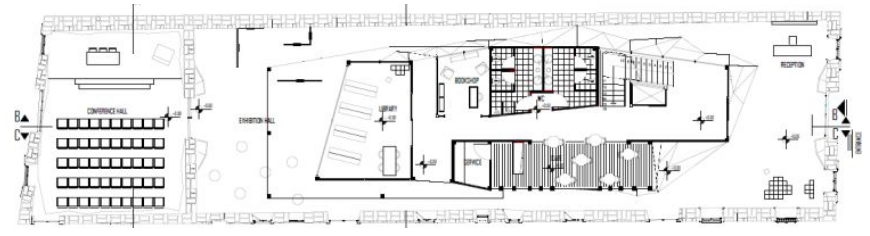

b

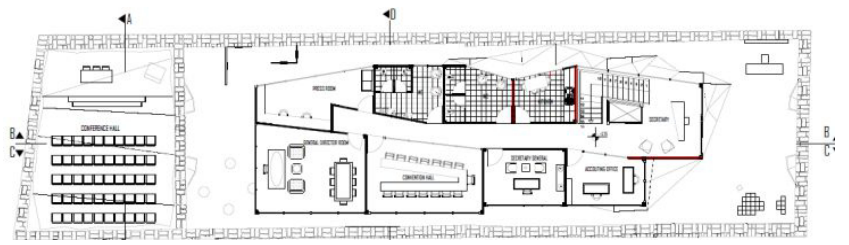

$\mathrm{c}$
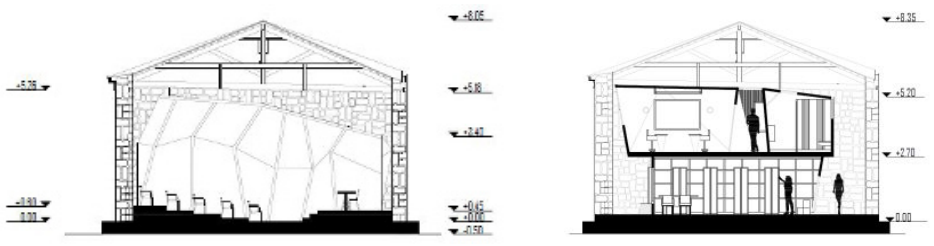

d

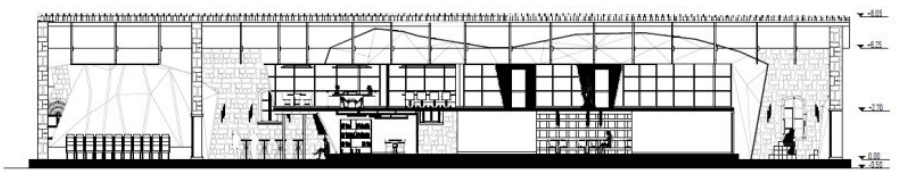

Fig.3. Student Project 1; (a)ground floor plan; (b)first floor plan; (c) section AA-BB; (d) Section CC (no scale) 
Starting with project 1; which is an example of preserved façade, exterior and partial interior masonry wall. Also there is a contemporary structural system addition which was a steel construction element used. The steel floating floor was centered in the plan and does not touching any of the interior façade. By this method masonry interior walls are not blocked with the mezzanine floor and tissues of the historical walls are emphasized (Fig. 3).

a

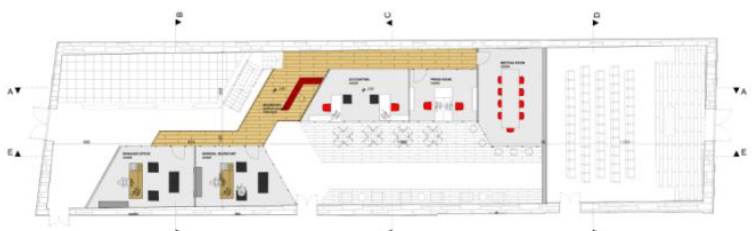

b

$:$ $\because$

$\mathrm{c}$

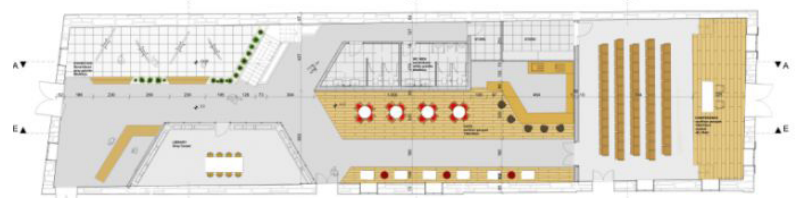

d
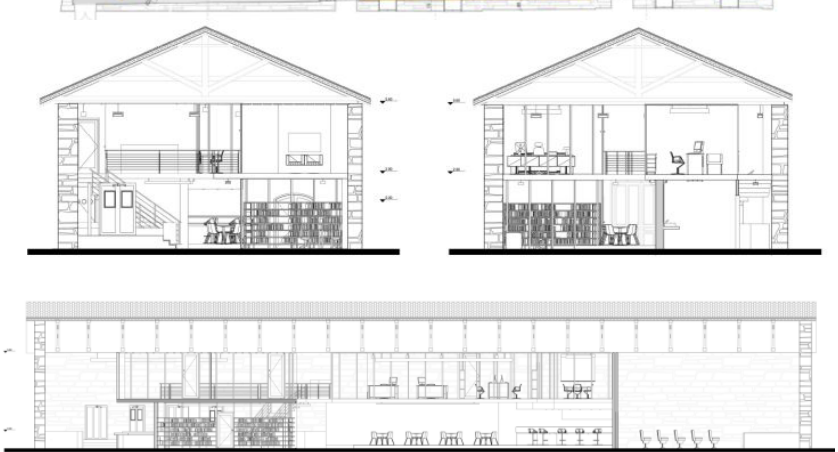

Fig.4. Student Project 2; (a)ground floor plan; (b)first floor plan; (c) section AA-BB; (d) section CC (no scale)

Project 2 is an example of preserved façade and exterior masonry wall. In this project timber structural system and wood decking used as an original mezzanine floor. By this timber system, building's original structural system is partially revitalized and also tissues of the historical walls are emphasized (Fig. 4).

a

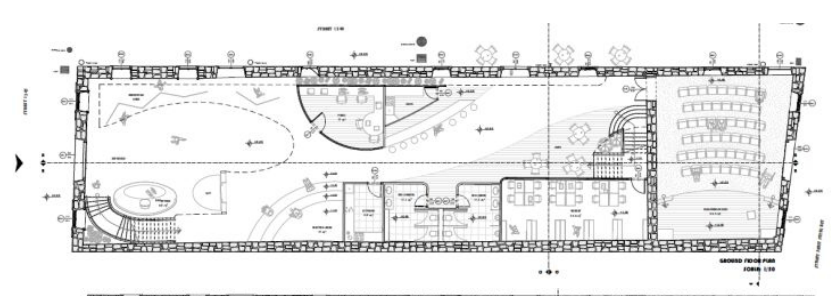

$b$

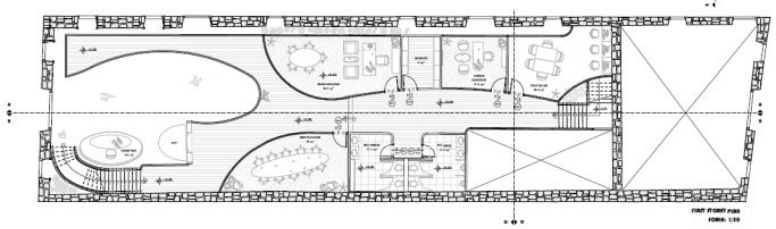


$\mathrm{c}$

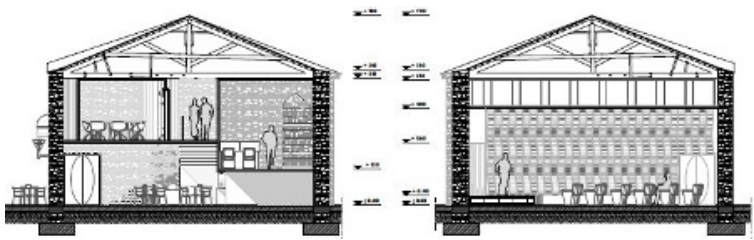

d

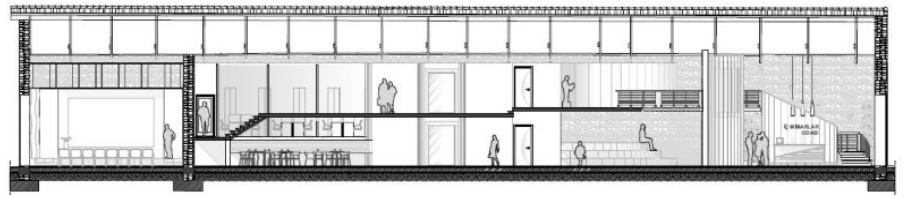

Fig.5. Student Project 3; (a)ground floor plan; (b)first floor plan; (c) section AA-BB; (d) section CC (no scale)

Project 3 is an example of preserved façade, exterior and partial interior masonry wall. Also, in this project there is an steel floating floor. The plan scheme was in organic, curved forms which were contrary to the original geometry of the plan. Again in this project, by this method masonry interior walls are not blocked with the mezzanine floor and tissues of the historical walls are emphasized. Among the other projects, in project 3, there is an additional window shade on the façade with contemporary materials (Fig. 5).

When all the projects were evaluated one by one due to each category that have defined in table 1; interventions on plan scheme and interventions on façade, are shown in table 2 and 3. Colored boxes expresses that the numbered project has the defined feature.

Table 2. Interventions on plan scheme

\begin{tabular}{|l|l|l|c|c|c|}
\hline Catogorios & $\begin{array}{c}\text { Conservation } \\
\text { of the orieinal } \\
\text { plan schemes }\end{array}$ & $\begin{array}{c}\text { conservation } \\
\text { of the } \\
\text { intrinsic } \\
\text { structural } \\
\text { condition }\end{array}$ & $\begin{array}{c}\text { Usage of } \\
\text { intrinsict } \\
\text { bullding } \\
\text { material } \\
\text { (interior } \\
\text { space) }\end{array}$ & $\begin{array}{c}\text { Usage of } \\
\text { contemporary } \\
\text { structural } \\
\text { addition }\end{array}$ & $\begin{array}{c}\text { Usage of } \\
\text { contemporary } \\
\text { material }\end{array}$ \\
\hline Project 1 & & & & & \\
\hline Projoct 2 & & & & & \\
\hline Project 3 & & & & & \\
\hline Project 4 & & & & & \\
\hline Project 5 & & & & & \\
\hline Project 6 & & & & & \\
\hline Project 7 & & & & & \\
\hline Project 8 & & & & & \\
\hline Project 9 & & & & & \\
\hline Project 10 & & & & & \\
\hline Project 11 & & & & & \\
\hline Project 12 & & & & & \\
\hline Project 13 & & & & & \\
\hline Project 14 & & & & & \\
\hline Project 15 & & & & & \\
\hline Project 16 & & & & & \\
\hline Project 17 & & & & & \\
\hline Project 18 & & & & & \\
\hline Project 19 & & & & & \\
\hline Project 20 & & & & & \\
\hline Project 21 & & & & & \\
\hline Project 22 & & & & & \\
\hline Project 23 & & & & & \\
\hline Project 24 & & & & & \\
\hline Project 25 & & & & & \\
\hline Project 26 & & & & & \\
\hline Project 27 & & & & & \\
\hline
\end{tabular}

In table 2 it is seen that none of the projects have remained the original plan schemes. In most of the projects have used the contemporary structural additions and contemporary 
materials such as; steel and glass. Masonry interior walls generally were not preserved. The distribution of each category is shown numerically in a bar graphic in table 3 .

Table 3. Interventions on plan scheme

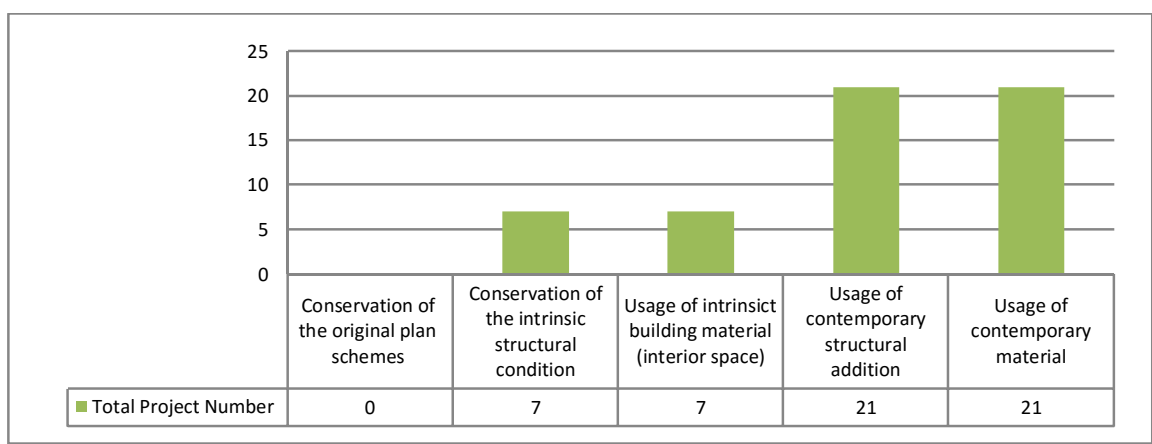

Table 4. Interventions on Façade

\begin{tabular}{|c|c|c|c|c|c|}
\hline Categories & $\begin{array}{l}\text { Conservation } \\
\text { of intrinsic } \\
\text { façade } \\
\text { system } \\
\text { (windows, } \\
\text { doors, } \\
\text { shutters, } \\
\text { arcs, etc.) }\end{array}$ & $\begin{array}{c}\text { Conservation } \\
\text { of the } \\
\text { intrinsic } \\
\text { façade } \\
\text { height }\end{array}$ & $\begin{array}{l}\text { Usage of } \\
\text { intrinsic } \\
\text { building } \\
\text { material }\end{array}$ & $\begin{array}{l}\text { Usage of } \\
\text { contemporary } \\
\text { structural } \\
\text { addition }\end{array}$ & $\begin{array}{c}\text { Usage of } \\
\text { contemporary } \\
\text { material }\end{array}$ \\
\hline \multicolumn{6}{|l|}{ Project 1} \\
\hline \multicolumn{6}{|l|}{ Project 2} \\
\hline \multicolumn{6}{|l|}{ Project 3} \\
\hline \multicolumn{6}{|l|}{ Project 4} \\
\hline \multicolumn{6}{|l|}{ Project 5} \\
\hline \multicolumn{6}{|l|}{ Project 6} \\
\hline \multicolumn{6}{|l|}{ Project 7} \\
\hline \multicolumn{6}{|l|}{ Project 8} \\
\hline \multicolumn{6}{|l|}{ Project 9} \\
\hline \multicolumn{6}{|l|}{ Project 10} \\
\hline \multicolumn{6}{|l|}{ Project 11} \\
\hline \multicolumn{6}{|l|}{ Project 12} \\
\hline \multicolumn{6}{|l|}{ Project 13} \\
\hline \multicolumn{6}{|l|}{ Project 14} \\
\hline \multicolumn{6}{|l|}{ Project 15} \\
\hline \multicolumn{6}{|l|}{ Project 16} \\
\hline \multicolumn{6}{|l|}{ Project 17} \\
\hline \multicolumn{6}{|l|}{ Project 18} \\
\hline \multicolumn{6}{|l|}{ Project 19} \\
\hline \multicolumn{6}{|l|}{ Project 20} \\
\hline \multicolumn{6}{|l|}{ Project 21} \\
\hline \multicolumn{6}{|l|}{ Project 22} \\
\hline \multicolumn{6}{|l|}{ Project 23} \\
\hline \multicolumn{6}{|l|}{ Project 24} \\
\hline \multicolumn{6}{|l|}{ Project 25} \\
\hline \multicolumn{6}{|l|}{ Project 26} \\
\hline Project 27 & & & & & \\
\hline
\end{tabular}

When the interventions on façade are evaluated, in most of the projects intrinsic façade systems were conserved and in all of the projects façade height was constant. When the intrinsic building materials on façade are observed, they were not changed. Almost half of the student projects have added contemporary additions such as shading elements and 
canopy, the materials of the additions were canvas, steel and glass. The distribution of each category is shown numerically in a bar graphic in table 5 .

Table 5. Interventions on Façade

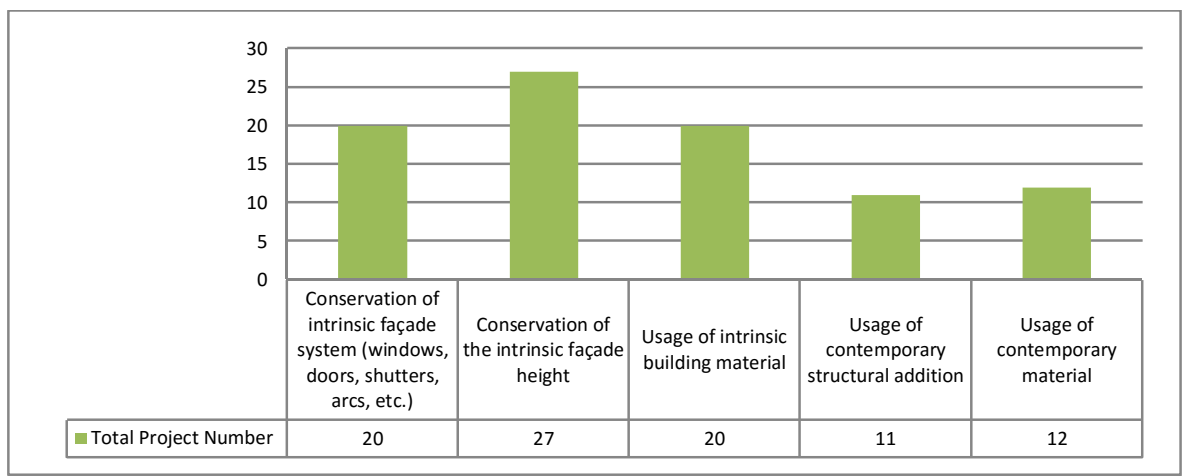

\section{Final remarks and conclusion}

Through the course of "Historical Cultural Heritage and Conservation" or other courses like with the similar topics, students will be trained to respect historical environment. So, interior architecture students can integrate the historical environment knowledge in studio project and the overall built environment. In addition to, students will be aware of conservation principles and regulations. The engagement between these two courses will inspire creative and sustainable design ideas.

When all the undergraduate students in interior architecture schools will be familiar with historical cultural heritage values and conservation principles; they will be more delicate to be respectful to the historical built environment.

\section{References}

1. Ahunbay, Z. Tarihi Çevre Koruma Ve Restorasyon, İstanbul; Yem Yayın., (1996).

2. Doğan, K. Ahşap Saraylar (Kaybolan Kent Hayalleri); Wooden Palaces of the Ottomans, İstanbul; Yem Yayın., (2001).

3. Eldem, S. H. Turk Evi (Turkish House), Istanbul: TAC Yayin., (1984).

4. Eldem, S. H. Turk Evi Plan Tipleri(Turkish House Plan Types), I.T.U. Mimarlik Fakultesi, Istanbul., (1968).

5. Eldem, S. H. Boğaziçi Yalıları I-II, İstanbul:Vehbi Koç Vakfi.

6. English Heritage. www.english-heritage.org.uk. Accessed January 2012., (1994).

7. Gür, Ş. Ö. Doğu Karadeniz Örneğinde Konut Kültürü. İstanbul; Yem Yayın., (2000).

8. Günay, R. Tradition of the The Turkish House and Safranbolu Houses, İstanbul; Yem Yayın., (1998).

9. Halicioglu, F. H. Analysis Of Vernacular Architecture in Terms of Sustainable Considerations: The Case of Şirince Village in Western Turkey. Alam Cipta, International Journal of Sustainable Tropical Design Research and Practice, 5(2), 3954., (2012).

10. Küçükerman, Ö. Turkish House In Search of Spatial Identity,İstanbul: Turkiye ve Turing Otomobil Kurumu., (1996).

11. Philokyprou, M. Teaching Conservation and Vernacular Architecture, Journal of Architectural Conservation, 17:2, 7-24., (2011). 
12. Rudofsky, B. Architecture without Architects: A Short Introduction to Non-pedigreed Architecture, NJ:Garden City., (1964).

13. Sözen, M. Turklerde Ev Kulturu (House Culture of Turks), Istanbul, Dogan Kitapcilik AS, (2001).

14. The Venice Charter. Icomos International Charter For The Conservation And Restoration Of Monuments, (1964). And Sites, http://www.icomos.org/charters/venice_e.pdf.

15. Yun, J. Rethinking vernacular architecture: the case of Hanoks in South Korea, The Journal of Architecture, 19:1, 108-127, (2014). DOI: 10.1080/13602365.2014.885555

16. Yürekli H., \& Yürekli, F. Türk Evi Gözlemler ve Yorumlar, İstanbul:Yapı Yayın., (2005). 